\title{
Numerical model of beam-to-column composite connection between slim floor system and composite column
}

\section{Modelo numérico de ligação mista viga-pilar entre piso misto de pequena altura e pilar preenchido}
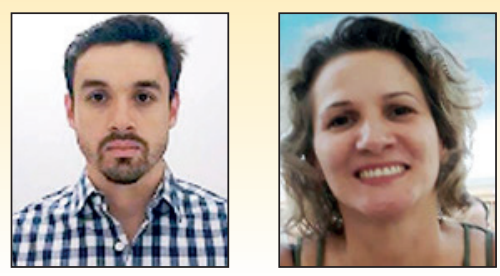

R. F. F. KOCHEM raimundokochem@gmail.com https://orcid.org/0000-0002-0081-777X

S. DE NARDIN a snardin@ufscar.br https://orcid.org/0000-0002-8736-4987

\begin{abstract}
The slim floor system has been used mainly due to the structural and constructive advantages of it, such as the capacity to overcome large spans with the low height of the composite floor system. There is a lack of finite element modelling researches of composite connections between the slim floor system and columns, especially with the concrete infilled steel tube columns. This paper presents the numerical approach based on the solid modelling, for the simulation of the nonlinear structural behavior of composite connection between partially encased composite beam and concrete infilled steel tube column; in this model, the composite beam represents the slim floor. The ABAQUS finite element code was used to investigate the behavior of composite connection that consists of a shear steel plate and negative reinforcement of the composite slab. In this paper, the authors discusses the procedures to the numerical model construction including finite elements and boundary conditions. Besides, the influence of stress-strain relationships for concrete and steel and the parameters that defines each model are presented and discussed, as well as the different steel to concrete interface conditions. Based on the results obtained, the effectiveness of the numerical model developed was verified against experimental results showing a good agreement response for the Moment vs. Rotation response, as well as the moment resistance of the composite connection.
\end{abstract}

Keywords: slim floor, composite connections, numerical analisys, shear steel plate, beam-to-column connection.

\section{Resumo}

A utilização do sistema de piso misto de pequena altura, de aço e concreto tem-se dado, principalmente, devido às boas características estruturais e construtivas como a capacidade de vencer vãos consideráveis com baixa altura do sistema laje-viga. Apesar disso, há carência de estudos voltados ao comportamento das ligações entre o sistema de piso de pequena altura e os pilares, sobretudo quando o pilar é misto preenchido. Diante disto, o presente estudo traz uma metodologia para o desenvolvimento de modelo numérico que represente o comportamento de uma ligação mista entre viga mista parcialmente revestida e pilar misto preenchido; a viga mista representa o piso misto de pequena altura. Para tanto foi utilizado o pacote computacional ABAQUS. A ligação mista viga-pilar consiste de chapa passante e armadura negativa da laje mista com fôrma de aço incorporada. São apresentados os procedimentos para a construção do modelo numérico, desde escolha dos elementos finitos e condições de vinculação, incluindo amplo estudo sobre o efeito dos modelos constitutivos dos materiais e dos parâmetros que definem cada modelo constitutivo dos componentes da ligação mista bem como das diversas interfaces aço-concreto. O modelo numérico mostrou-se bastante robusto e representou de forma satisfatória a resposta Momento vs. Rotação bem como a rigidez inicial e o momento resistente da ligação mista.

Palavras-chave: piso misto de pequena altura, ligações mistas, modelagem numérica, ligação com chapa passante, ligação viga-pilar. 


\section{Introduction}

The association of steel profile and concrete resulting in steelconcrete members reduces the local bucking of steel profile and increases the properties of concrete specially the brittle failure. Therefore, the use of composite members explore the most favorable properties of both, concrete and steel under compression and tension respectively. Besides the fact that the steel-concrete have very good structural properties, the use of this composite structure have positive impact on the constructive process due to the possibility of utilize pre-fabricated components reducing the time labor and construction cost as well as the construction waste. These are examples of composite members: beams, columns, slabs and connections. The steel-concrete composite flooring systems are composed by composite slab and beams and depending where de slab is rest on the beams the system can be conventional or slim. The conventional flooring system consists of a composite slab sitting on the top flange of the beam connecting through the deck by the use of welded shear studs connections. The overall depth of the composite flooring is the sum of the steel profile and composite slab heights (Figure 1a). On the other hand, in the composite slim floor systems the concrete slab sits on the bottom flange of the steel profile reducing the overall depth of the slab-beam system (Figure 1b). Reduction of the overall depth of the composite floor and increase of the local buckling resistance of the steel profile are reached when the position of the slab is changed in relation to the steel profile. The resulting system can achieves spans ranging 5 to $9 \mathrm{~m}$ [1] with high fire resistance [2]. Despite the structural benefits very interesting of the composite slim floor systems, have been a few studies about this type of flooring, especially concerning tests. In this context, Lawson et al. [3] conducted a serious of tests on partially encased composite beams and present analytical models to predict the bending moment resistance and the steel-concrete shear bond strength. The procedure proposed by Lawson et al. [3] taken into account two stages: the construction stage in which the steel profile supports the weight of the concrete slab and other construction

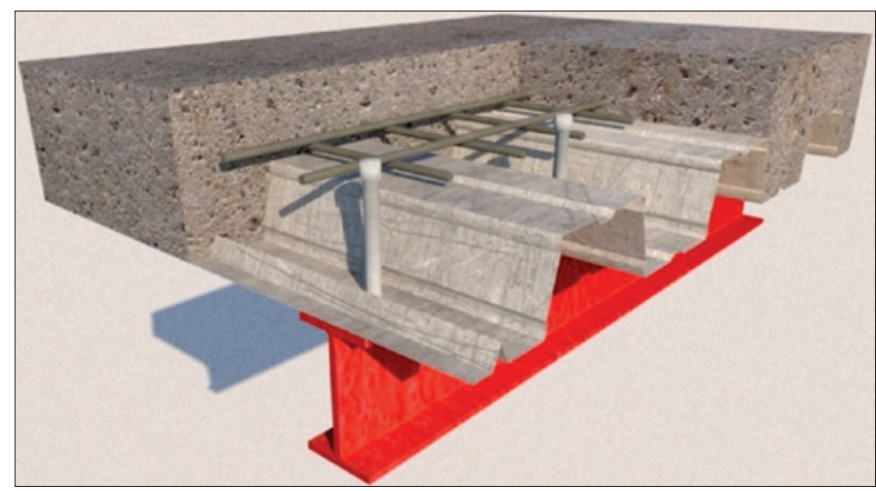

(a) Conventional composite floor loads and the composite beam that occurs after the concrete cured and the composite section is formed by the steel profile and the concrete slab. Ramos [4] developed a numerical model and this model was verified by the experimental results of Lawson et al. [3] to validate the numerical approach. A parametric study was carried out to investigate the influence of concrete strength, the thickness of concrete on the steel profile and the reinforcement ratio. The results showed little difference of the moment capacity due to the increase on the concrete strength of slab. On the other hand, it was recorded a direct relation between the depth of concrete on the steel beam and the moment capacity. Regarding to the reinforcement ratio, higher ratios reduce the cracking especially on the application region [4].

Headed shear studs welded on the top flange connect the concrete slabs to the steel beam to form the conventional composite beams. The overall depth of the composite slim floor is increased if headed shear studs are welded on the top flange. Therefore, in this type of composite floor is necessary to investigate other positions for the shear connectors. An experimental study [5] investigated innovative positions for the headed shear studs in partially encased composite beams. Three composite beams were tested and the headed studs were welded in two positions: vertically on the bottom flange and horizontally on the faces of the web. Also was tested a reference specimen without headed studs [5]. Comparing with the reference specimen, the most remarkable position seems to be the headed studs vertically welded on the bottom flange because in this case it was recorded higher bending moment capacity and lower concrete-steel [5]. Wang et al. [6] also investigated the influence of the reinforcement ratio and conducted a series of tests. The variation on the reinforcement ratio had little influence on the flexural stiffness but when the ratio was increased, it was observed higher bending moment capacity.

Many manufactured and prefabricated members form the composite slim floor systems and due this, there is no monolithic connections as in the reinforced concrete structures. For this reason, the connection can be designed taking into account aspects as the performance and the moment capacity necessaries to the adequate global and local behavior of the structure.

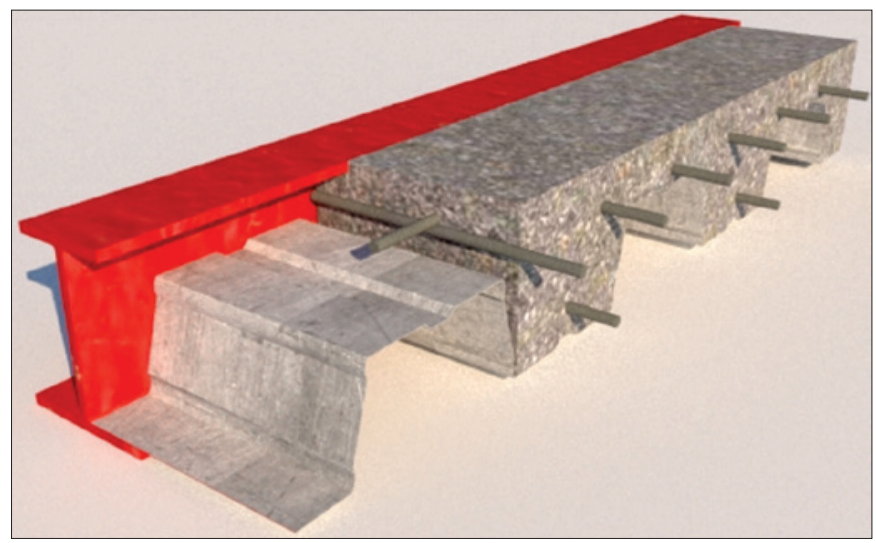

(b) Slim floor system

\section{Figure 1}

Configuration of composite floor

Font: Authors 
The strength, ductility and stiffness of the steel connections can be significantly improved by composite action i.e., considering the contribution of the concrete slab in the moments transfer. Therefore, in a composite connection the reinforcing bars of the concrete slab contribute to the moment transfer. Previous study have shown even beam-to-column pinned connections possess some degree moment capacity and rotational stiffness. This occurs because the reinforcing bars of concrete slab offer already continuity and contribute to increase the strength and stiffness of ordinary steel frames even the [7].

The current version of the Brazilian Standard Code [8] introduces a series of recommendations to evaluate the moment resistance, the rotation capacity and the stiffness of composite beam-column connection. However, the specific details of connections included in the standard code are: flush endplate joint, seating cleat with double web cleats joint and seating cleat joint. For all these specific connection details, it were considered steel columns and composite slab or reinforced concrete slab but for both, the slab rests on the top flange of the steel beam (conventional floor, Figure 1a). Therefore, there are not composite beam-column connections considering the concrete-filled steel tube column and the slim floor system and the present study contributes to the decrease this lack of knowledge.
The current information about the composite connections in steelconcrete conventional flooring can be adapted for slim floor systems, provided that it have been considered the influence of the connected members and the steel-concrete interaction on the nodal zone [1].

About the connections involving the composite slim floor, an experimental study evaluate the influence of parameters as column type (steel profile or square concrete-filled steel tube column), reinforcing ratio of slab $(0.2$ and $0.5 \%)$ and connection type ( $T$ or cruciform connection) on the connection behavior of partial endplate joint [1]. Afterwards a study showed that contribution the of the slab leads to increase of the stiffness and moment capacity of the beam-to-column [9]. Malaska [9] investigated the influence of reinforcement ratio of the slab, shear-to-moment ratio and concrete strength on the beam-column composite connection of the slim floor system. The beam-to-column connection was a shear flat slotted through the wall of the tube column section and bolted to the steel beam web by four bolts in two rows. A concrete-filled rectangular hollow steel section was used as column. The slim floor beam was an asymmetric built-in steel beam section partially encased in the slab. The slab consists of in situ concrete and a profiled metal decking supported on the lower flange of asymmetric steel beam. The com-
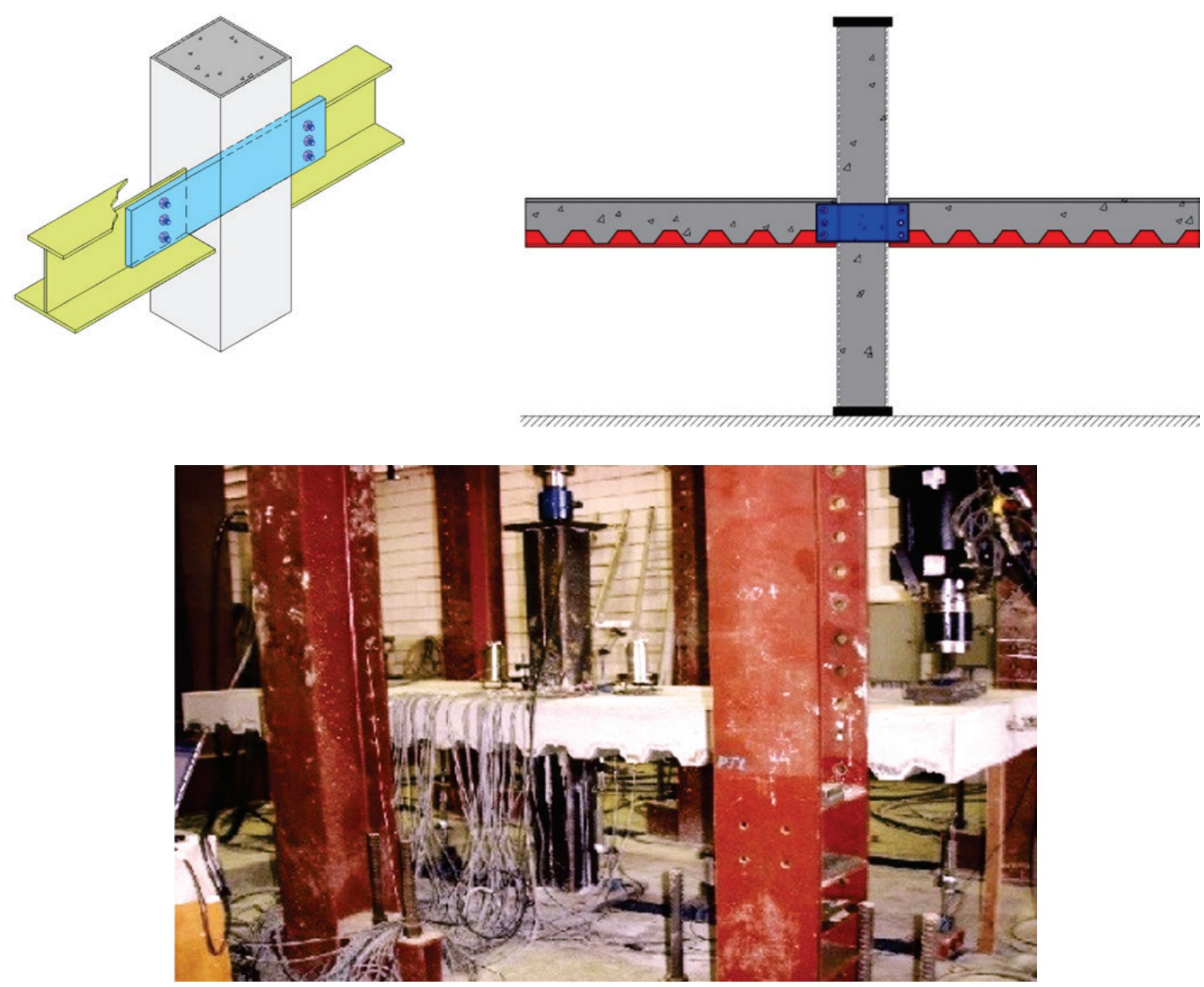

Figure 2

Set up of specimen tested by De Nardin \& El Debs [10] 
posite behavior was provides by transverse steel bars welded on the top flange of the steel beam for resisting the vertical separation and the shear slip between the steel beam and the concrete slab. These steel bars act as shear connectors and provide the steelconcrete interaction in the slim floor beam. The results showed the concrete strength and the shear-to-moment ratio have no effect on the joint moment-rotation. Considering the values of moment resistance and initial stiffness the tested composite connection was classified as rigid connection and partial resistance [9].
A very important Brazilian study evaluated the composite connection between the composite slim floor and the concrete filled steel tube column [10]. The column was connected to the asymmetric slim floor composite beam using a shear flat plate and three bolts. The composite action was provided by headed studs welded on the lower surface of the top flange of the asymmetric steel beams. Details of the specimen geometry and the main results used to validate the numerical modelling are given in the item 2 . The tested composite connection presented nonlinear behavior since the first
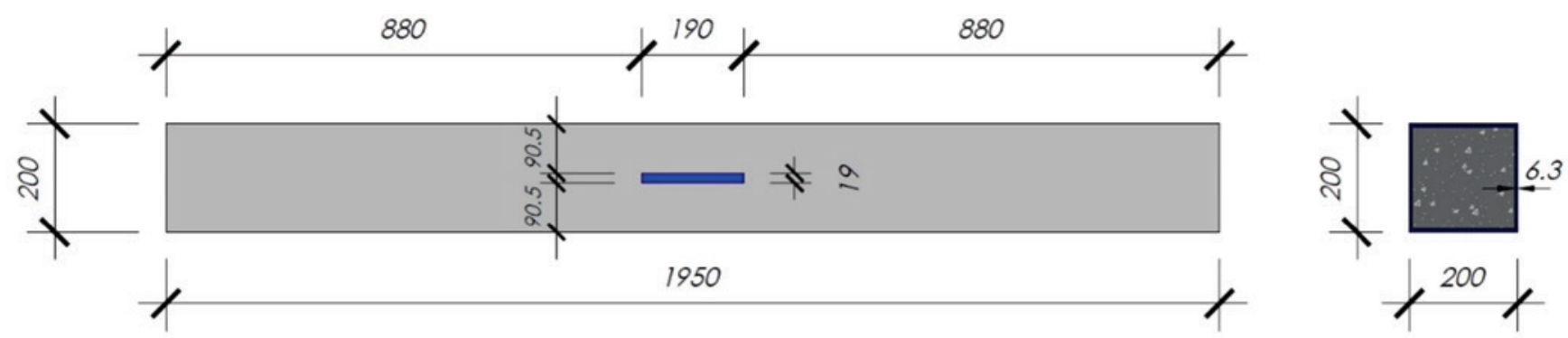

a) Concrete filled steel tube column
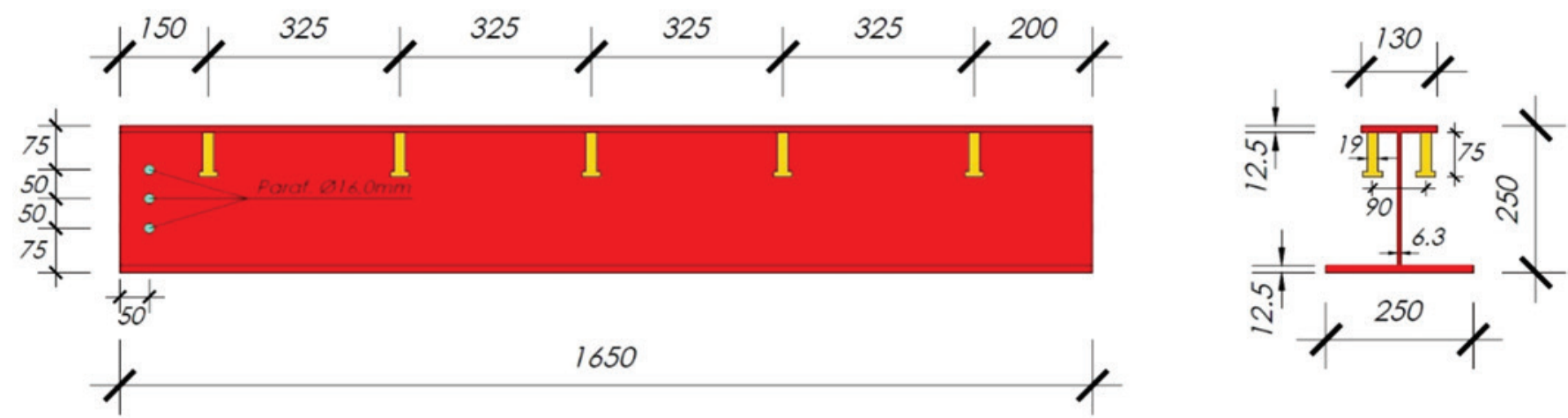

b) Asymmetric slim floor beams

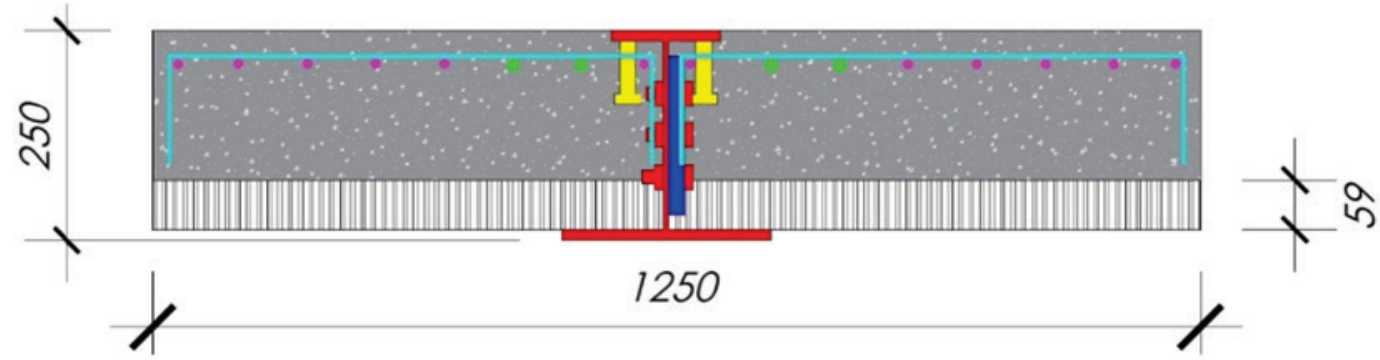

c) Composite beam cross section

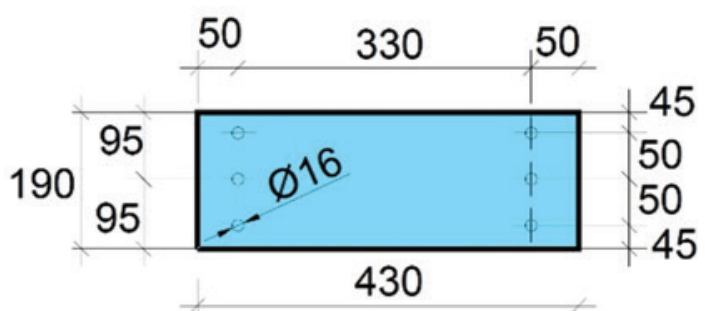

d) Shear flat plate

\section{Figure 3}

Details of asymmetric slim floor composite beams and composite column [10]. Dimensions: mm 
stages of loading, especially after the concrete cracking of the slab was started [10]. The presence of the concrete slab significantly changed the response of the connection improving the force transfer between the composite floor and the column [10].

Although the composite structures have been extensively used in engineering practice, there are a few details of composite connection included in the national and international standard procedures. Another very important point is the beam-to-column connection details not include the composite columns. The study of the beam-tocolumn behavior considering composite slim floors are very rare in both Brazil and other countries.

The summary presented here gives an overview of the lack of studies about composite connections involving composite columns and asymmetric slim floor composite beams. Furthermore, the few found studies are about the behavior of the asymmetric slim floor composite beams. Therefore, the present study contributes to increase the knowledge about composite connections in which a concrete filled steel tube column is connected to the composite floor by shear steel plate. The main aim is the development of a Finite-Element (FE) numerical approach to predict the composite connection behavior between the slim composite floor and a square composite column. The development and validation of the numerical model is an important step in order to future parametrical studies to increase the results found in the literature. A brief description of the reference test used in the numerical simulation is given in the follow item.

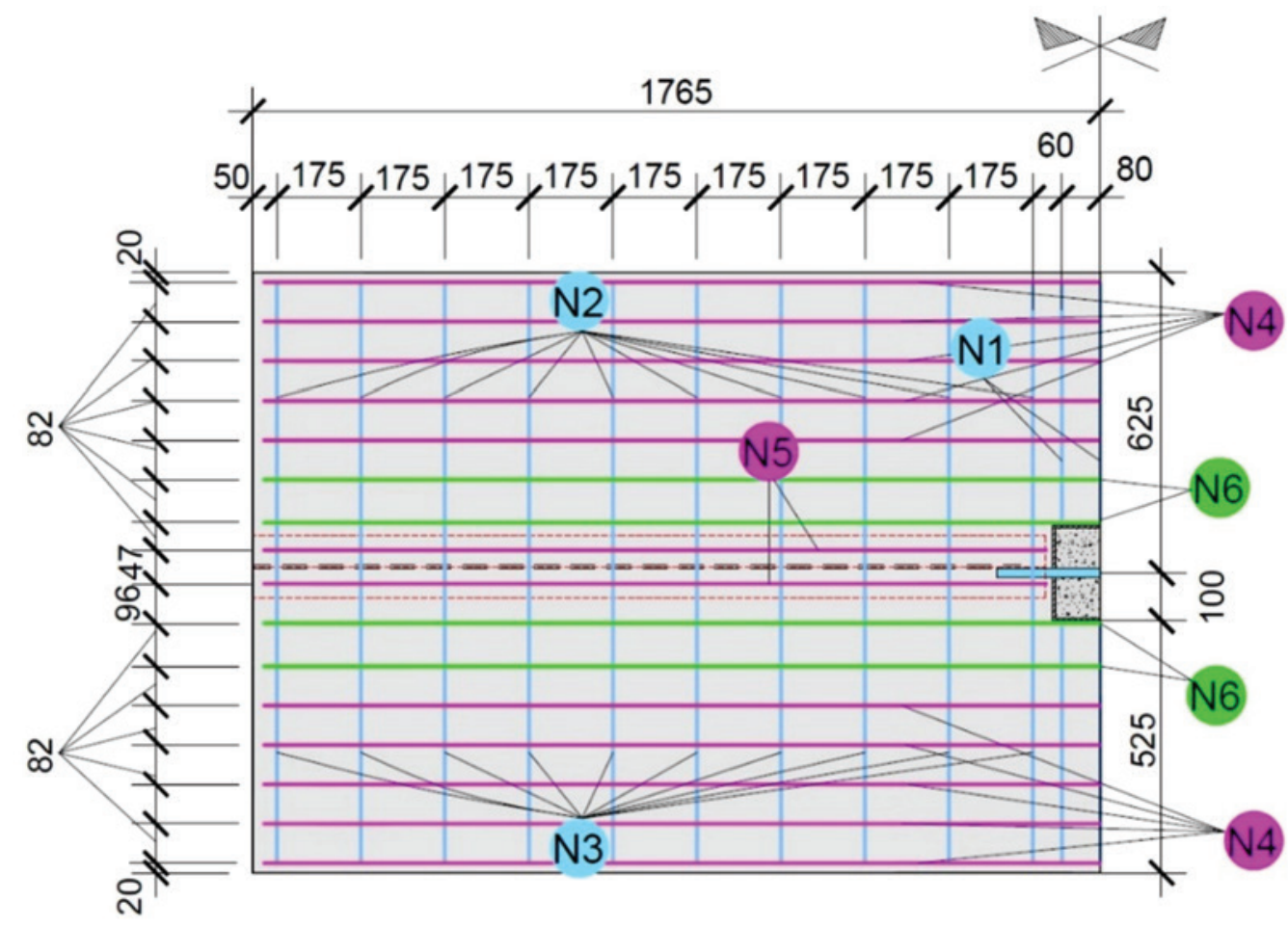

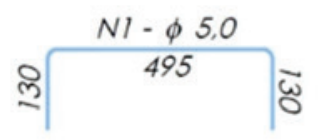
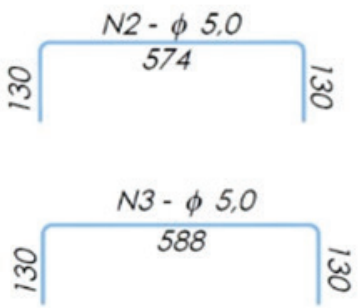
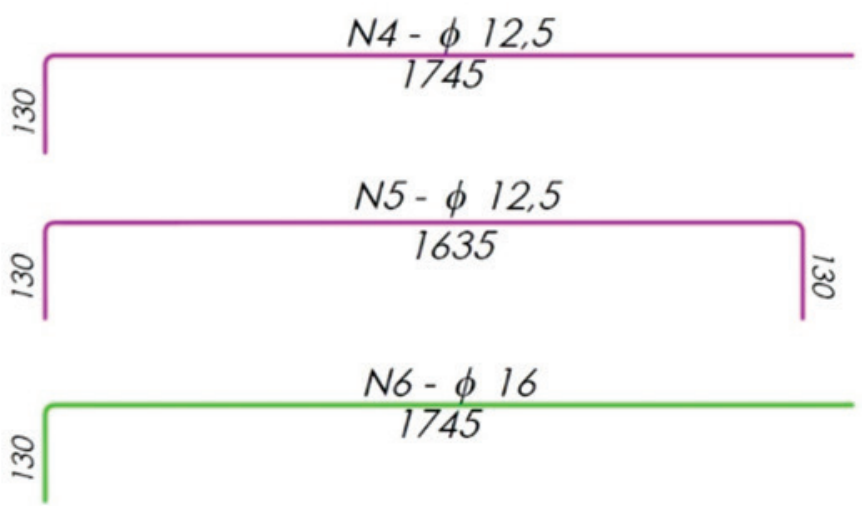

\section{Figure 4}

Reinforcement detailing in the reference experimental model. De Nardin and El Debs [10] 
Table 1

Material mechanical properties, MPa

\begin{tabular}{cccccccc}
\hline \multicolumn{2}{c}{ Column } & \multicolumn{2}{c}{ Slab } & \multicolumn{2}{c}{ Beam } & Bolt & Plate \\
\hline Steel & Concrete & Steel & Concrete & Flange & Web & - & - \\
$f_{y}=253$ & $f_{c}=69$ & $f_{y}=593$ & $f_{c}=30.1$ & $f_{y}=305$ & $f_{y}=297$ & $f_{y}=702$ & $f_{y}=287$ \\
- & $f_{f}=3.5$ & $\varepsilon_{y}=2.58 \% \circ$ & $f_{f}=2.1$ & $f_{u}=420$ & $f_{u}=410$ & $f_{u}=911$ & $f_{u}=399$ \\
- & $E_{c}=38090$ & - & $E_{c}=28220$ & - & - & - & - \\
- & - & - & $\varepsilon_{c}=1.80 \% \circ$ & - & - & - & - \\
\hline
\end{tabular}

Table 2

Finite elements used in the numerical model

\begin{tabular}{|c|c|c|}
\hline Finite element & Description & Application \\
\hline C3D8R & Linear solid element & $\begin{array}{l}\text { I-shaped section, steel flat plate, bolts, concrete } \\
\text { slab and concrete core of composite column }\end{array}$ \\
\hline B31 & $\begin{array}{c}\text { Beam element, allows axial strains, curvature } \\
\text { variation and torsion }\end{array}$ & Headed studs connectors \\
\hline T3D2 & Bar element - axial strains & $\begin{array}{l}\text { Reinforcing bars of the composite slab and } \\
\text { composite connection }\end{array}$ \\
\hline
\end{tabular}

\section{Reference experimental result}

A very important part of a numerical modelling is to validate and calibrate a numerical procedure to represents a real problem. For this purpose, some experimental results of De Nardin and El Debs [10] were used to verify the degree of accuracy of the numerical models. The tested composite connection was composed by two asymmetric slim floor composite beams, a composite column, and composite slab with profiled steel decking. The steelwork connection consists of a shear flat slotted through the wall of the hollow column section and bolted to the steel beam web using a single row of three bolts (Figure 2). This shear flat plate was not welded to the composite column. The composite column is a square steel tube column filled with $\mathrm{C} 70$ concrete (Figure 3a). The height of the column section is $200 \mathrm{~mm}$ and the thickness is $6.3 \mathrm{~mm}$.

The composite beams were made of welded asymmetric slim floor beam using A-36 steel (Figure 3b). The quantity and distribution of the headed studs were determined by a specific study [5]. Profiled steel decking Polydeck $59 \mathrm{~S}$ with $59 \mathrm{~mm}$ height were used in the composite slab. These $f$ profiled steel decking were rested on the bottom flange of the I-profile of the composite beam and kept in its position by using small points of weld. The negative reinforcing bars are the responsible for the beam-to-column composite connection. In the present research, the negative reinforcement comprised four $\phi 16 \mathrm{~mm}$ and fourteen $\phi 12.5 \mathrm{~mm}$ rebars, disposed longitudinally by both sides of the composite column. In the transverse direction, $\phi 5 \mathrm{~mm}$ rebars were disposed by both column sides as negative reinforcement in the direction orthogonal to the beams [10] (Figure 4). The shear flat plate details are given in Figure 3d. The slim floor was connected to the composite column by $16 \mathrm{~mm}$ ASTM-A325 bolts disposed in a single row (Figure 2). The steel plate was made of ASTM-A325. Table 1 shows the average values of the main mechanical properties of the materials.

Regarding the experimental program, concentrated loads were applied to the beams ends and to the composite column. The load on the column was kept with a constant value of $600 \mathrm{kN}$ during the test (Figure 5). The load applied on the beams ends until the connection ultimate load capacity was reached were controlled using displacement control. The values of composite beam displacements ( $1 \mathrm{~V}$ to $6 \mathrm{~V}$, Figure 5 ) and connection rotation were used to validate the numerical model. The rotation was calculated from the displacement measured in the nodal region $(1 \mathrm{H}$ to $4 \mathrm{H}$, Figure 5$)$.

\section{Numerical model}

The numerical model was developed using the finite element program ABAQUS [11], version 2017. The finite elements presented in Table 2 were used to model each of the components of the reference real scale model (item 2). C3D8R finite element was chosen due to its capacity of performing good results with smaller computational costs and also avoiding the increase of the strength capacity, shear locking effect, that is a fact outlined by different authors [12-15].

The present research made use of more than one finite element when modelling the thickness of bent elements, in order to compensate excessive strain (hourglassing effect), as it was made in Rocha [14]. The headed studs were modelled using beam elements type B31. Such elements represent the reinforcement satisfactorily as far as its behavior are similar to the rebars, resisting mostly to

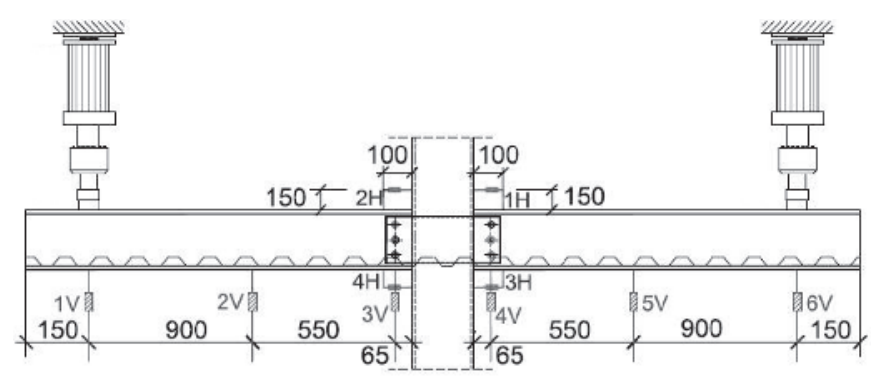

Figure 5

Points of displacement measurements [10] 


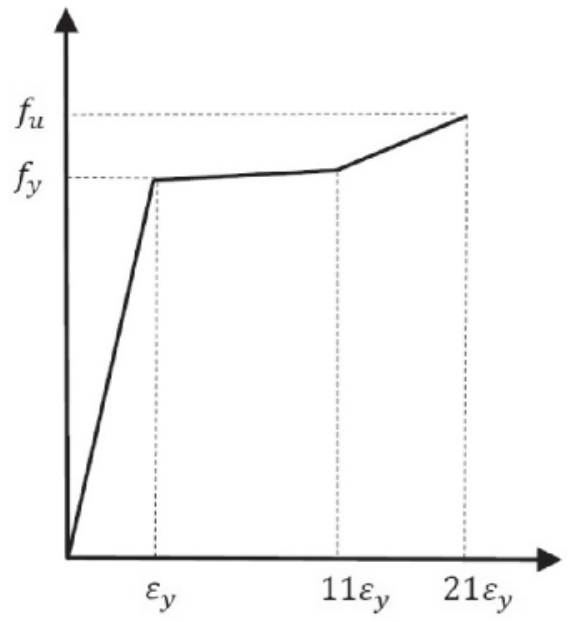

a

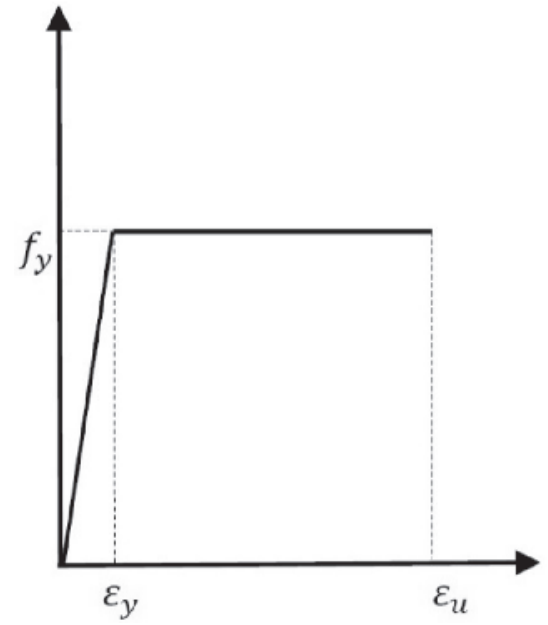

c

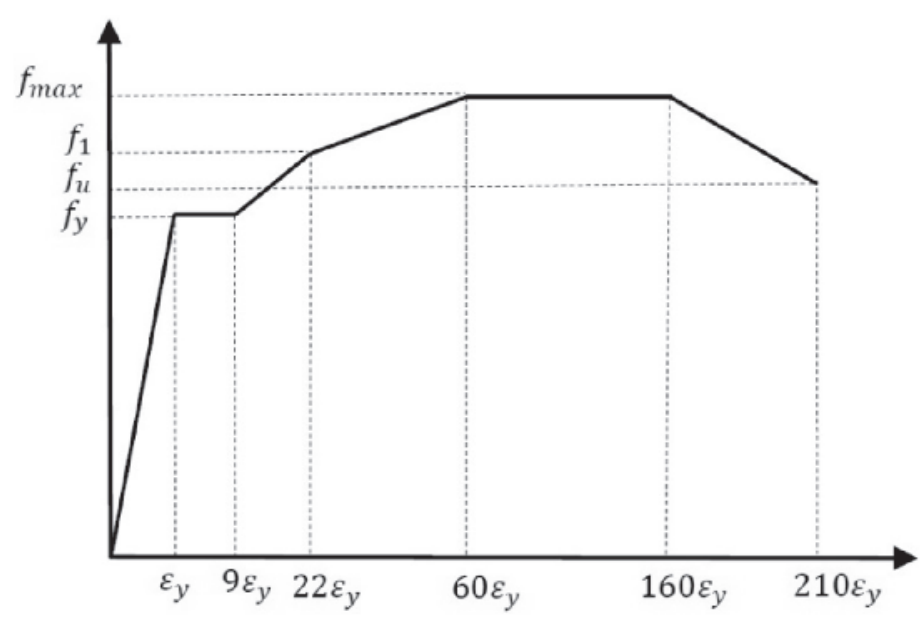

b

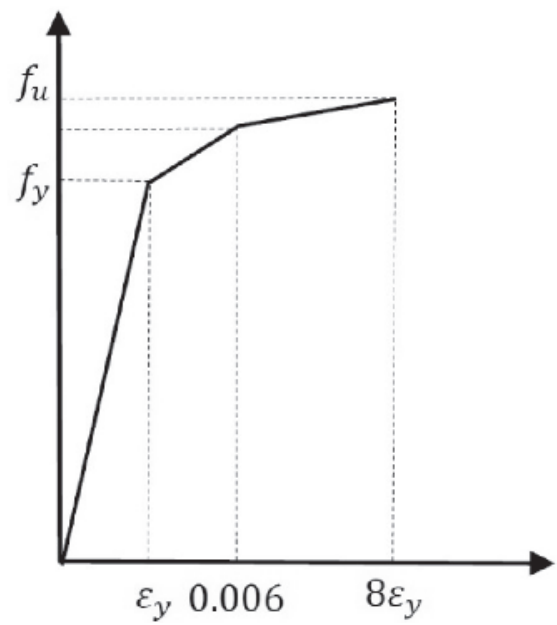

d

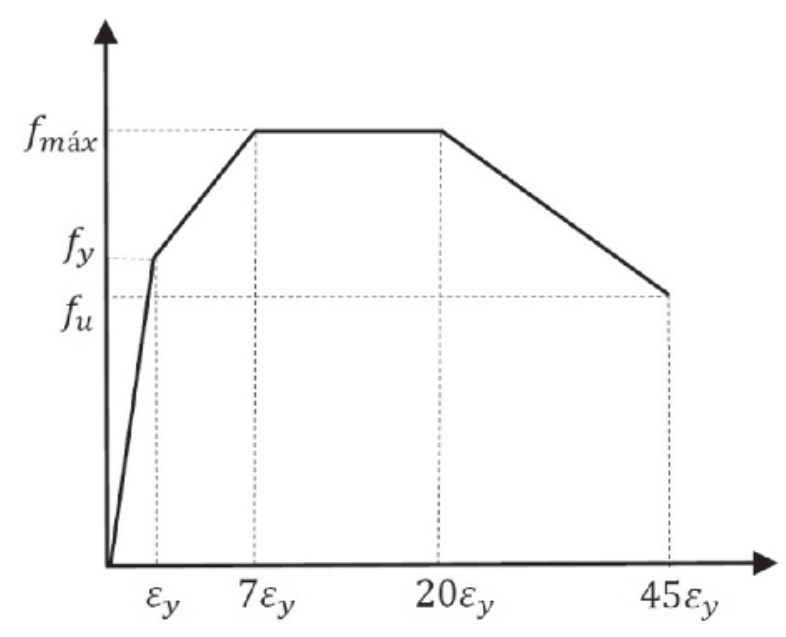

e

Figure 6

Constitutive models for steel elements 
axial forces. The influence of the type of finite element or the mesh density on the numerical model answer were no evaluated during the modelling process. The main parameters influencing the composite connection global response are presented subsequently.

\subsection{Constitutive models}

Different concrete and steel constitutive models were evaluated in order to examine the influence of material constitutive models when representing an experimental test. In order to simulate the steel plate and steel section behavior (mono-symmetrical I-shaped tubular section), the models which Axial Stress vs Strain relationship are shown in Figure 6 were analyzed: Sherbourne \& Bahaari [16] model (Figure 6a), Maggi [17] model (Figure 6b) and perfectly elastoplastic model (Figure 6c). The behavior of shear connectors and bolts was simulated using Sherbourne \& Bahaari [16] and Maggi [17] models, besides the perfectly elastoplastic model shown in Figures 6d, 6e and 6c, respectively.

For the reinforcing bars, the perfectly elastoplastic behavior was adopted considering the values of $\varepsilon_{y}$ and $f_{y}$ given in Table 1 and the ultimate strain $\left(\varepsilon_{u}\right)$ of $10 \%$. The modulus of elasticity was 200 GPa for all steel components. Moreover, nominal stress and strain values were adjusted in accordance with Eurocode 3:2006 [18] in order to consider real stresses and strain.
The strength criterion Concrete Damage Plasticity (CDP) was adopted to simulate the concrete behavior. This model is based on the Plasticity Theory and Damage Mechanics and it simulates the loss of stiffness of concrete after reaching its maximum strength, either under tensile or compressive stresses. This damage model is defined by parameters as angle of dilation $(\psi)$, eccentricity $(e)$, viscoplasticity $(v)$, proportion of distances between hydrostatic axis and tension and compression meridians in the cross section (K), ratio between compressive strength in biaxial and uniaxial states $\left(f_{b 0} / f_{c 0}\right)$, Stress vs Strain relationships for tension and compression, and damages under tension and compression. Physically, the angle of dilation represents the internal friction angle of the concrete and its value varies between $36^{\circ}$ and $40^{\circ}$.

The eccentricity $(e)$, given by $f_{t} / f_{c}$ relationship, is the length (measured along the hydrostatic axis) of the segment between the hyperbole vertex and the intersection of this hyperbole asymptotes [19]. Kirchhof [20] points out that the eccentricity does not have a physical meaning, although it can improve the numerical model convergence. Therefore, its influence on the numerical model was analyzed considering the following values: $0.0697,0.25$ and 0.50 . The viscoplasticity $(v)$ is the parameter that settles the constitutive equations, improving the convergence of models with materials that can lose stiffness, for example, due to shrinkage. For structures with concrete, the usual value for $v$ varies between 0 and

\section{Table 3}

Constitutive model for the concrete

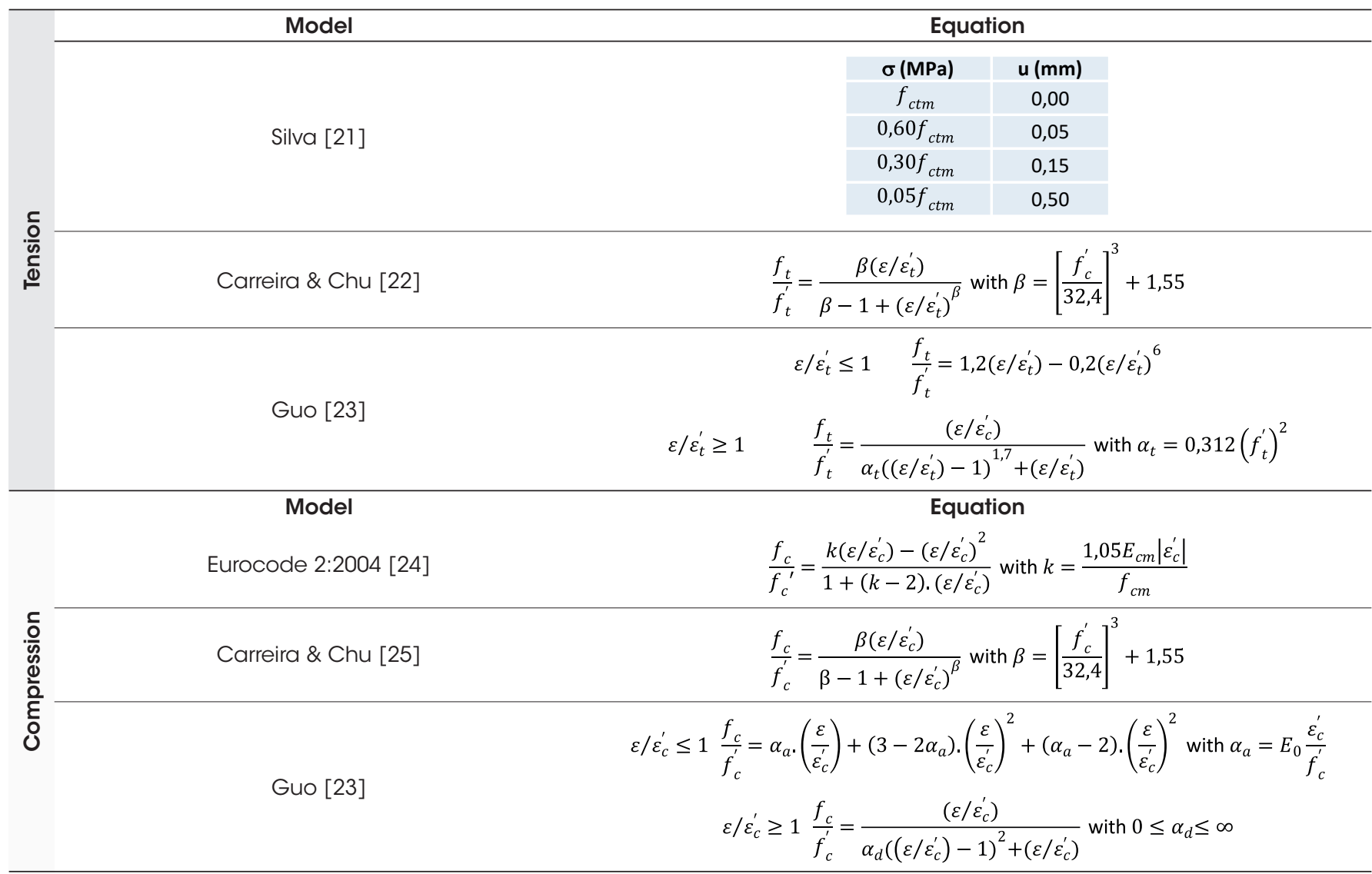


0.001 ; its influence was evaluated considering values of $0.1,0.01$ and 0.001 . The manual of the software ABAQUS [11] recommends the adoption of a proportion of distances between the hydrostatic axis and the meridians in the cross section equal to $K=2 / 3$, and the relationship $\mathrm{f}_{\mathrm{b} 0} / \mathrm{f}_{\mathrm{c} 0}$ equal to 1,16 .

In order to analyze the influence of the slab's concrete constitutive model in the numerical model response, there were used three constitutive models for tension and compression each, according to Table 3. The concrete core was assumed to have a linear elastic behavior in all analysis, as it has demonstrated a low level of strain during the experimental test.

\subsection{Coupling, boundary conditions, mesh and loads}

In order to represent the physical model and its interfaces, it is necessary to make use of couplings and boundary conditions. Hence, different segments were coupled such as some degree of freedom of an element node were jointed to another element's node. The shear connectors were jointed to the beam section using the command merge, that allows the connection of two pieces resulting in a single piece, even if they are described by several materials and finite elements.

As no separation was observed between bolts' heads and plates, plates and the infilled column concrete core, bolts' nuts and beam section, and tubular section and infilled concrete core, the tie constraint was used between these contact surfaces. The constraint between reinforcement and concrete slab was made using embedded region command, that constrained the translation degrees of freedom of the reinforcement to the slabs'. The behavior of stee and concrete materials was also modeled using embedded region command. This modelling method was used by other researchers in previous studies $[15,16]$.

Regarding the boundary conditions, in order to model the column

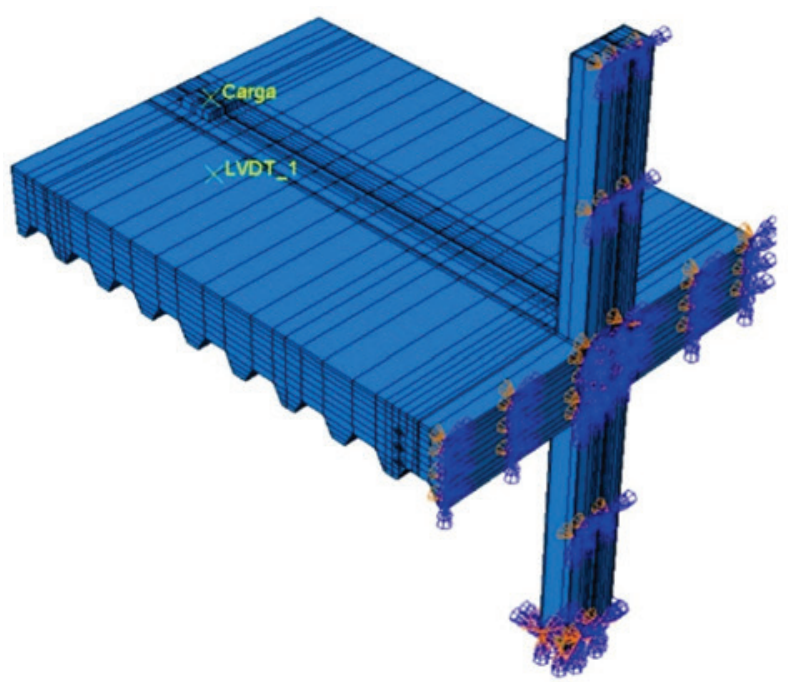

(a) Constraints and boundary conditions

Figure 7

Symmetry, constraints and finite element mesh base, the encastre command was used and the rotations and displacements were restrained in all directions. A vertical symmetry plane was considered passing by the center of the concrete infilled column (Figure 7a); the command XSYMM was used for this purpose. Although a specific study about the mesh density influence was not carried out, the connection components were split until regular and coincident meshes were obtained. The creation of meshes was made using the Sweep technique with medial axis algorithm (Figure 7b).

Different from the experimental test, forces were applied only to the beams ends in the numerical model, at a distance of $1,500 \mathrm{~mm}$ of the column external face. These forces were incrementally applied with initial value of 0.01 , minimum of $1.10 \mathrm{E}-10$ and maximum of 0.1 . Even though a compression force of $600 \mathrm{kN}$ was applied to the top of the column during the experimental test, experimental and numerical results show that this force has no influence in the numerical analysis. Hence, this force was eliminated in the final numerical model.

\subsection{Contact interactions}

Considering the contact interactions makes a numerical model much more realistic, however it implies in higher computational costs. The mechanical behavior of contact interactions is characterized by parameters such as the behavior in normal and tangential directions, dumping, damage and fracture. Among them, the most relevant ones for the present research are the behavior in normal and tangential directions to the contact surface. Moreover, since the beam-to-column connection specimen has two different materials, steel and concrete, both steel-steel and steel-concrete interactions are necessary in order to make the model more representative of the test.

In the case of steel-steel interaction, the tangential direction was represented by the frictionless model, with no friction, aiming that

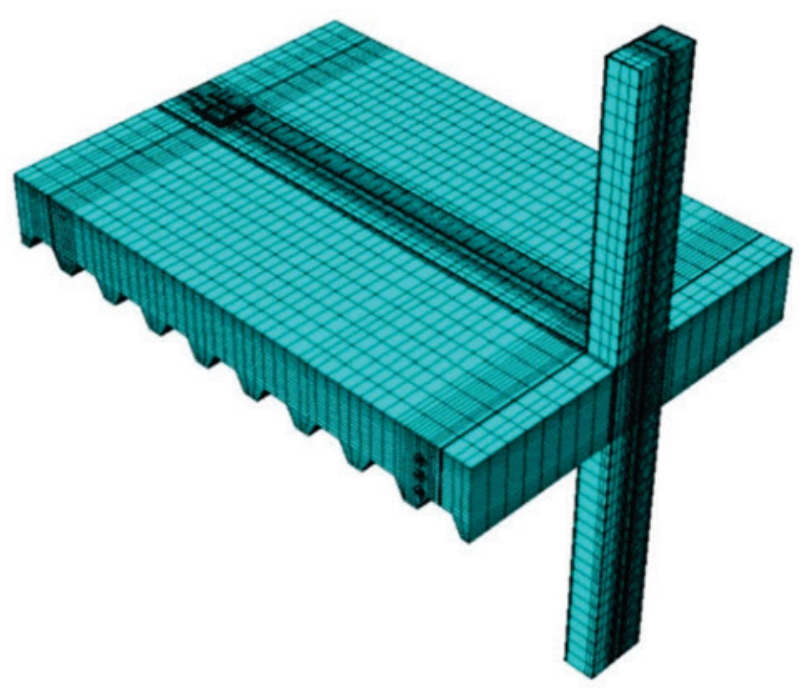

(b) Finite element mesh 
Table 4

Constitutive models for steel and concrete considering steel-concrete perfect bond

\begin{tabular}{|c|c|c|c|}
\hline Model & Steel & Concrete under compression & Concrete under tension \\
\hline Model 1 & Maggi [17] & & \\
\hline Model 2 & Sherbourne \& Bahaari [16] & Eurocode 2:2004 [24] & Silva [21] \\
\hline Model 3 & Perfectly elastoplastic & & \\
\hline Model 4 & & Guo [23] & Guo [23] \\
\hline Model 5 & Maggi [17] & Carreira \& Chu [25] & Carreira \& Chu [22] \\
\hline Model 6 & & Eurocode 2:2004 [24] & Silva [21] \\
\hline Model 7 & Maggi [17] & & \\
\hline Model 8 & Sherbourne \& Bahaari [16] & Guo [23] & Guo [23] \\
\hline Model 9 & Perfectly elastoplastic & & \\
\hline Model 10 & & - & - \\
\hline Model 11 & Perfectly elastoplastic & - & - \\
\hline Model 12 & & Eurocode 2:2004 [24] & Silva [21] \\
\hline
\end{tabular}

the contact surfaces slip without restrictions. In the normal direction, the hard model and the augmented Lagrange method of restraint application were adopted, with the possibility of separation of surfaces when subjected to tension and full stress transmission with no penetration when subjected to compression. The steelsteel interaction was considered between the steel plate and the beam web, between bolts and steel plate holes, and between bolts and beam web holes. Concerning the steel-concrete interaction, the tangential direction was characterized by the penalty friction model, with the following variations of coefficient of friction: 0.10 , $0.25,0.50$ and 0.75 ; the normal direction was defined by the same equations of steel-steel interaction.

The steel-concrete interaction was represented in the following contacts: between beam and slab, between slab and steel plate, between the column section and the slab, between the bolts' heads and the slab, and between the bolts' nuts and the slab. It is worth mentioning that, however some values of coefficient of friction considered herein does not have any physical meaning, they are mathematical artifices used as an attempt to approximate the steel-steel and steel-concrete contact representation to the real test behavior. Further comments regarding the values of coefficient of friction adopted in the present research are discussed in item 4.2. The obtained results are presented and discussed hereinafter.

\section{Results and discussion}

The following parameters concerning the numerical model response were evaluated: constitutive models, contact interactions and parameters of Concrete Damage Plasticity (CDP) model. The numerical model validation was made against comparative analysis of Moment vs Rotation responses of the present model and the reference experimental model [10]. Hereinafter, the results of each parameter evaluated are presented.

\subsection{Influence of constitutive models considering perfect bond}

In a first stage, the influence of material constitutive models on the numerical response was analyzed. For this purpose, the headed studs were removed and no contact interaction was introduced to replace it. The condition of perfect bond between components using the tie constraint tool was consequently imposed.

In order to evaluate the steel constitutive model, the Eurocode 2:2004 [24] model was adopted for the concrete in compression and Silva [21] model was adopted for the tensile concrete, as both of them were kept constant. Some parameters of the Concrete Damage Plasticity (CDP) model was remained constant at this stage: $\psi=36^{\circ}, e=0,0697, v=0,001, K=2 / 3$ e $f_{b 0} / f_{c 0}=1,16$. The influence of steel constitutive models was analyzed considering the combinations presented in Table 4 (Models 1 to 3 ). For all the analysis presented, the behavior of the reinforcing bars was represented using the perfectly elastoplastic constitutive model. A brief description of the main parameters related to the constitutive models is presented in Table 3.

The analysis of the influence of steel constitutive model demonstrated Moment vs Rotation responses (Table 4, Models 1 to 3 ) with insignificant variation between each other and a behavior with higher strength and stiffness capacity than the physical model. Even that the results were very similar, the multilinear constitutive model of Maggi [17] (Figure 6b), Model 1, was selected from this stage to be applied in further simulations. This choice was based in the advances presented by the aforementioned model in comparison to the others, describing the physical model behavior and showing a linear elastic initial path followed by yielding. Details about these results can be found in Kochem [27].

The next step comprised the evaluation of the concrete constitutive model combining the multilinear model of Maggi [17] for all steel components except for the reinforcement (perfectly elastoplastic model). The constitutive model for itself was analyzed with no variation in the concrete plasticity parameters. The combinations presented in Table 4 (Models 4 to 6) were made in order to choose the most adequate constitutive model for the concrete.

Concerning the results, a great influence of the concrete constitutive model was observed in the numerical model response, different than what was observed in case of steel. The adoption of Eurocode 2:2004 [24] constitutive model combined with Silva [21] - Model 06 - lead to a stiffer behavior in comparison to other combinations. Another important aspect: the combination of models of 


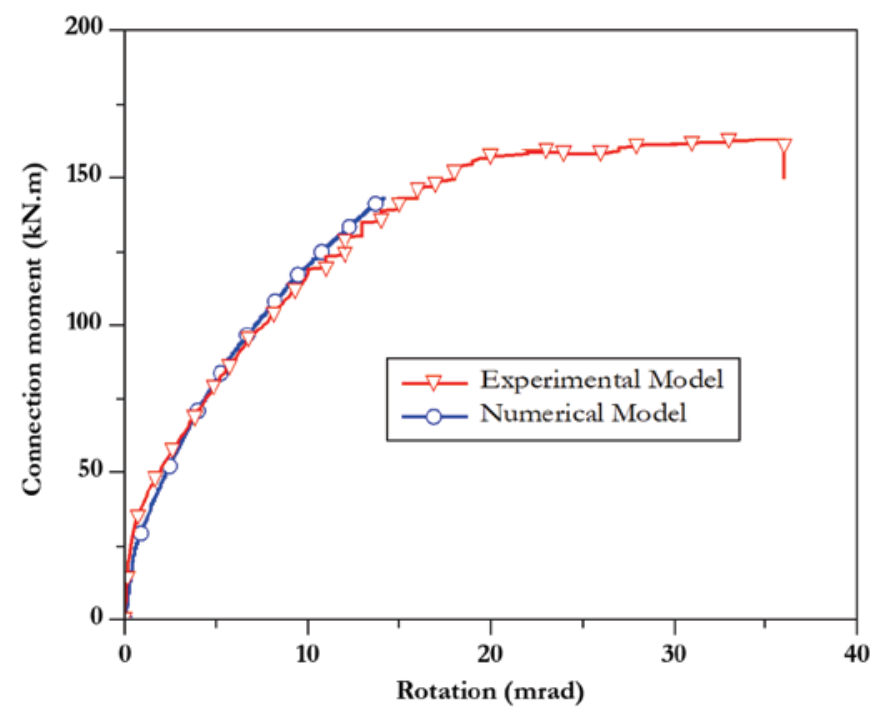

\section{Figure 8}

\section{Comparison of numerical vs. experimental} results considering contact interactions

Carreira \& Chu [25] and Carreira \& Chu [22] - Model 05 - showed some converging issues and the processing was interrupted with approximately $65 \%$ of load applied. The graphs corresponding to this stage are shown in Kochem [27].

Considering the results obtained and the constitutive model variations observed for both steel and concrete, a prior selection was made for further analysis: Maggi [17] multilinear constitutive model for steel elements, perfectly elastoplastic model for the reinforcing bars and Guo [23] model for the concrete. Furthermore, perfect bond was considered for all aforementioned analysis, by means of the tie constraint tool and without headed studs. The numerical model presented stiffer behavior than the experimental result. Due

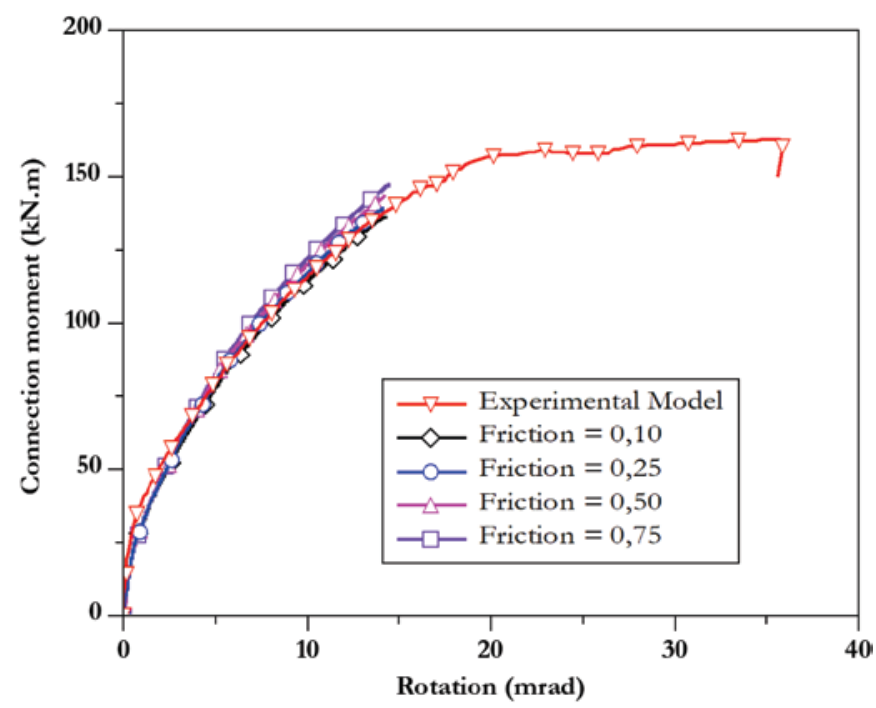

Figure 9

Influence of steel-concrete friction coefficient this, in the new analyses the headed studs were modelled considering the contact interactions between the components, aiming better representation.

\subsection{Numerical model with contact interactions considerations}

The contact interactions were considered, as described in item 3.3, adopting a steel to concrete coefficient of friction equal to 0.50 - value adopted by Amadio, Bedon \& Fasan [15] when simulating composite connections. The shear connectors modelling was made using B31 finite elements, according to item 3 , and the behavior of materials was represented by constraining shear connectors to the slab (item 3.2).

The shear connectors modelling and the consideration of contact interactions resulted good agreement between numerical and experimental models (Figure 8). However, the numerical model showed converging issues and the analysis was interrupted for bending moment values much slower than the ultimate experimental bending moment (Figure 8). The global response showed good agreement against the experimental results, indicating the need for small adjustments in order to improve the numerical model convergence (Figure 8).

The influence of the coefficient of friction was evaluated in order to improve the model convergence, considering the values: 0.10 , 0.25 and 0.75 , besides the value of 0.50 already analyzed. The value of 0.25 was adopted by other authors $[13,28]$ when simulating composite connections. The choice of 0.75 was made considering it was close to the steel to concrete coefficient of friction adopted by McCormick et al. [29], although it seems to be a high value. The obtained results indicate it is not a parameter of great influence in the numerical model response (Figure 9). Besides its small influence, the response with best agreement to the experimental one was achieved when using a coefficient of friction of 0.10 . The slightly stiffer result was obtained using the value 0.75 . Therefore, the steel to concrete coefficient of friction was adopted as 0.10 for further analysis.

\subsection{Influence of concrete damage plasticity parameters}

Considering that the numerical model now shows good agreement to the experimental one, some parameters of concrete damage model were analyzed in order to achieve responses even closer to the experimental test. It is important to mention that the current numerical model includes shear connectors constrained to the concrete slab using the embedded region command. The steel elements behavior is represented by Maggi [17] multilinear model, the reinforcement is modeled according to the perfectly elastoplastic model, the concrete is modeled according to the model of Guo [23] and the steel to concrete interactions are modeled with 0.10 coefficient of friction.

Some authors relate convergence issues to the limitation of the concrete damage plasticity model when associated to finite elements type C3D8R [20]. Modifying the parameters of concrete plasticity is an alternative to reach better convergence. Hence, two new simulations were carried out varying the following parameters: eccentricity (e), viscoplasticity ( $v$ ) and angle of dilation $(\psi)$. 


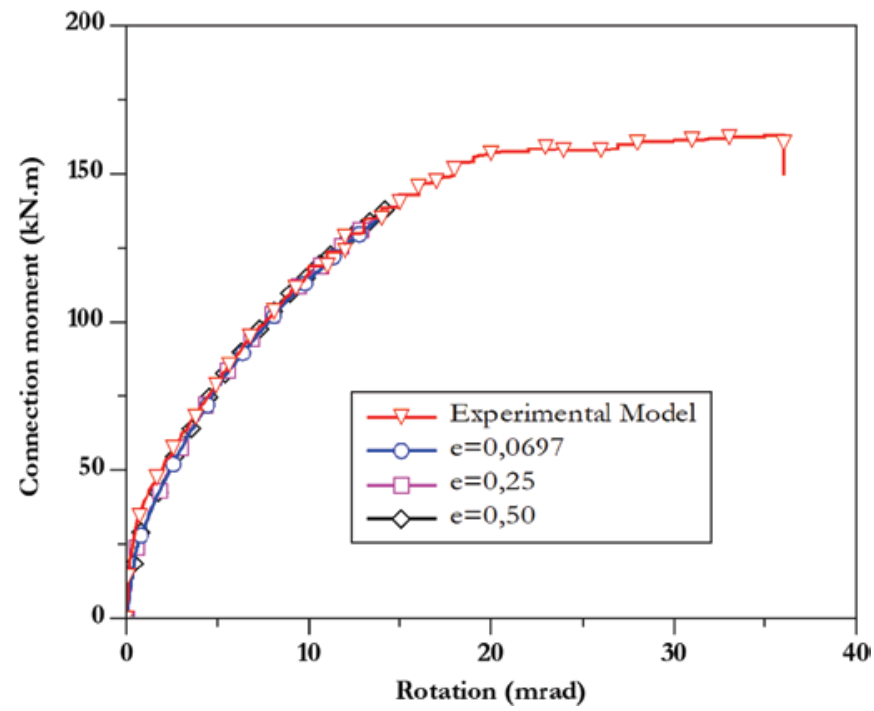

Figure 10

Influence of the eccentricity parameter (e)

Among these parameters, the eccentricity (e) obtained from the ratio $f_{t} / f_{c}$ does not have any physical meaning, even though its variation consists in a numerical artifice used to adjust concrete damage plasticity model limitations [20]. This option was evaluated considering the following eccentricity values: $0.0697,0.25$ and 0.50 [20]. Insignificant influence of eccentricity in the model's behavior was observed, either for its convergence or for its global response (Figure 10). Therefore, the default value 0.0697 was chosen to the kept for the eccentricity.

Another alternative evaluated to overcome these convergence issues was to make the viscoplastic constitutive equations regularization. It makes the tangential stiffness of the material to be positive for sufficiently small increments. The software adopts the

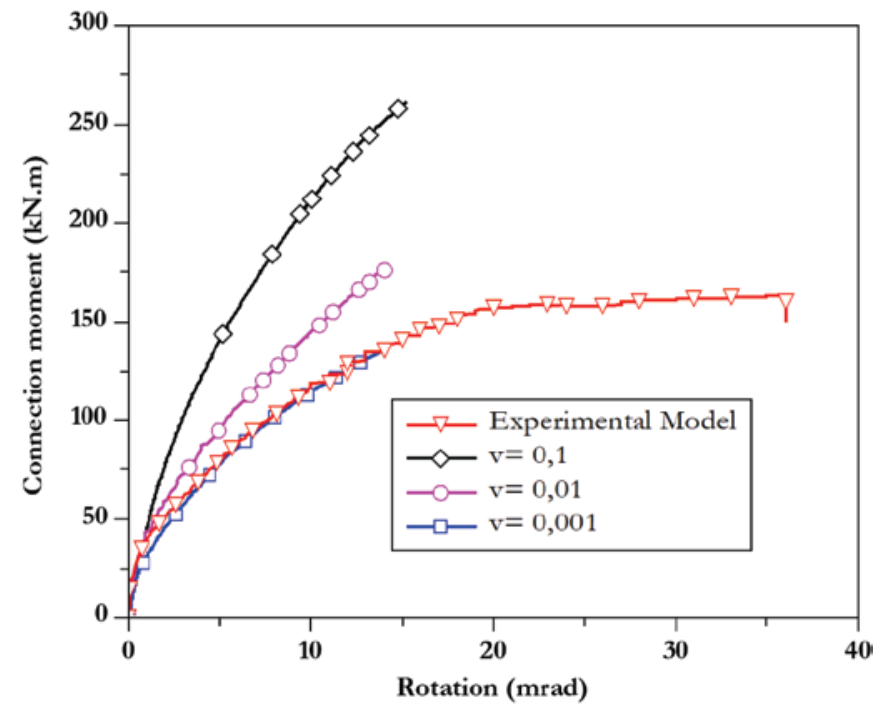

Figure 11

Influence of viscoplasticity parameter (v) viscoplasticity value as zero as default so that no viscoplastic settling is made. However, this default value lead to serious convergence issues and the analysis was interrupted during the primary load increments.

Aiming to improve the analysis convergence, the following viscoplasticity values were evaluated: $0.10,0.01$ and 0.001 . Differently from the eccentricity, viscoplasticity showed great influence in the convergence and global behavior of the composite connection (Figure 11). At the same time, there was a considerable stiffness increment that deviated the numerical and experimental responses (Figure 11). Based on this behavior, the viscoplasticity was kept equal to 0.001 - value that was already used in the previous studies.

The dilation angle of the concrete damage plasticity model was also evaluated in the present research in order to reach better convergence results. It was taken as $36^{\circ}, 37^{\circ}, 38^{\circ}, 39^{\circ}$ e $40^{\circ}$ (Figure 12). As the dilation angles was increased the numerical model response showed a slightly stiffer response. Due this, the angle of dilation was kept equal to $36^{\circ}$.

\subsection{Influence of the constitutive model associated to the contact interactions}

Since the analysis presented so far in this research did not lead to significant convergence improvement, a new analysis was carried out associating the constitutive models to the contact interactions. In the additional analysis, the constitutive models presented in item 3.1 and the contact interaction - taking the steel to concrete coefficient of friction equal to 0.01 as indicated in item 4.2 - were considered. The first attempt in order to improve convergence consisted in modifying the constitutive model of steel, keeping constant the constitutive model of concrete (Table 4, Models 7 to 9). There was a significant advance in convergence (Figure 13) especially when adopting the perfectly elastoplastic behavior for all of the steel components (Model 9).

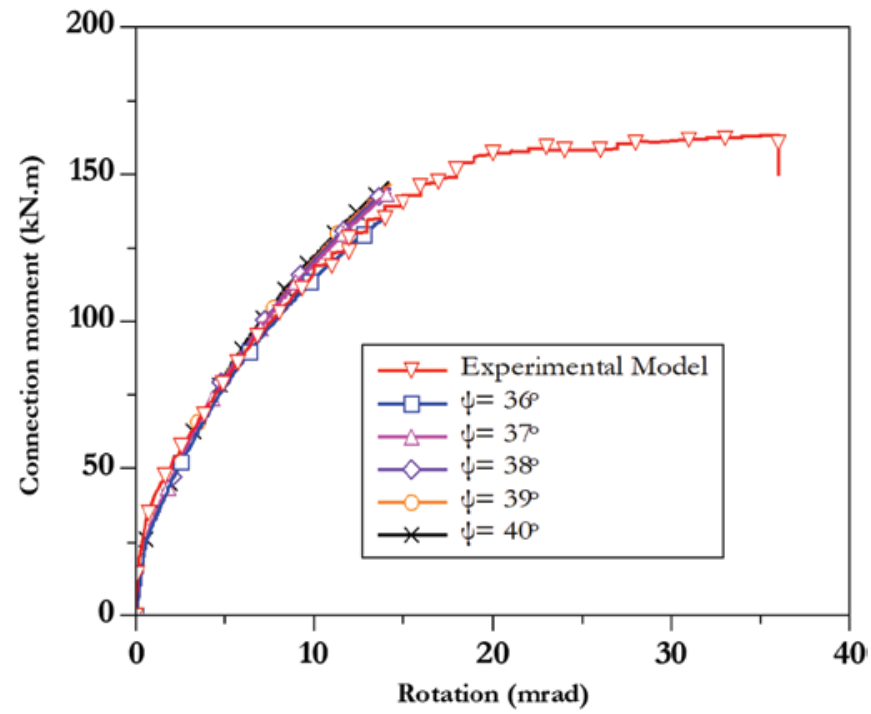

Figure 12

Influence of dilation angle $(\psi)$ 


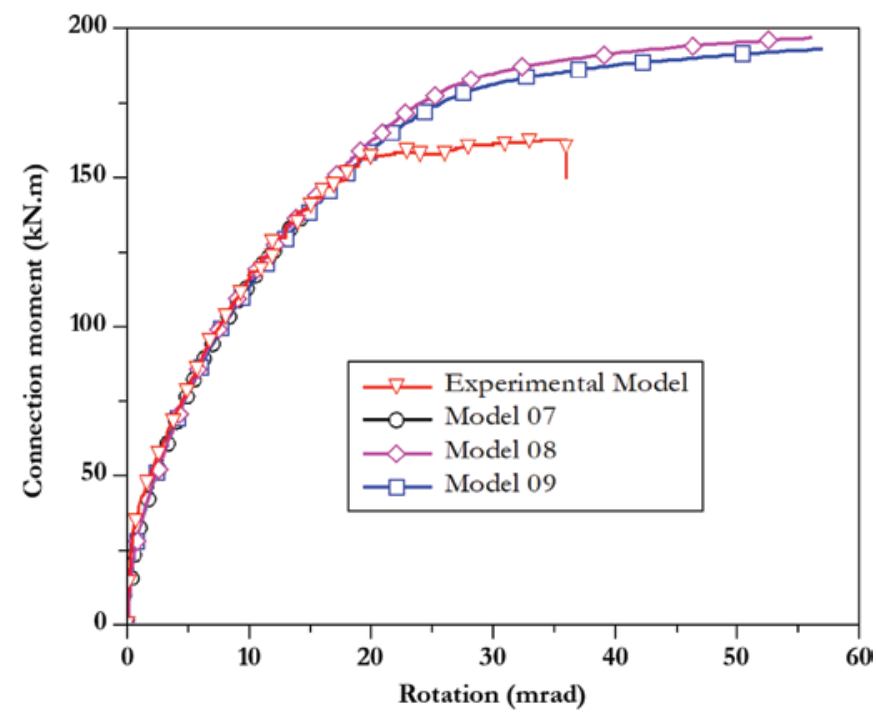

Figure 13

Influence of steel constitutive model considering contact interactions

Once the perfectly elastic-plastic constitutive model was set for all steel components, the next step consisted in analyzing the influence of concrete constitutive model in the numerical model, maintaining constant the parameters of concrete damage plasticity model. In Table 4, the tests using a different concrete constitutive model are presented (Models 10 to 12). The combination of Eurocode 2:2004 [24] and Silva [21] models (Model 12), for concrete in compression and tension respectively, resulted in a very stiff behavior with convergence issues for low levels of applied force (Figure 14). Hence, because of these results (Figure 14), the Guo [23] model was maintained for concrete either in tension or compression.

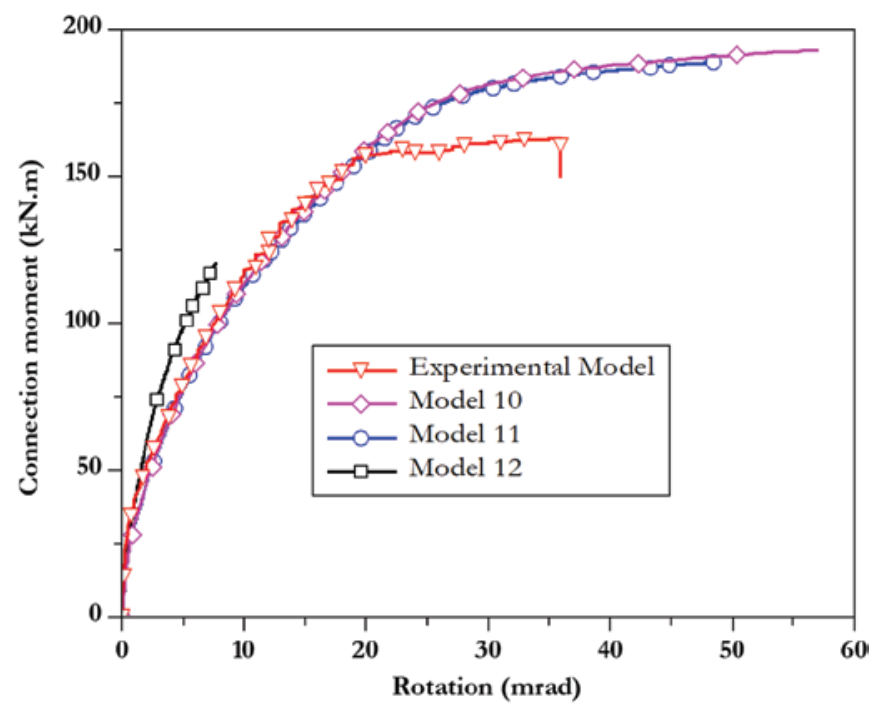

\section{Figure 14}

Influence of concrete constitutive models associated to contact interactions
Because it is in a region of negative bending moment, the connection behavior has great influence of the concrete behavior when subjected to tension. In the constitutive model of Guo [23], the concrete behavior under tension is strongly influenced by the parameter $\alpha_{t^{-}}$. It occurs as the increase of this parameter turns the Stress vs Strain descendent curve segment more concave, reducing the connection stiffness. Therefore, aiming to improve the numerical model representation, the following $\alpha_{\mathrm{t}}$ values were analyzed: 1.38 , 4.0, 6.0 and 8.0. The results (Figure 15) show better numerical model response for $\alpha_{t}=0.6$. For higher values, convergence issues were found and the analysis was interrupted before the plastification of any connection component (Figure 15).

\subsection{Final numerical model}

The numerical model with the best Moment vs Rotation curve agreement in comparison to the experimental results has the following characteristics: steel elements with perfectly elastoplastic behavior, concrete constitutive model described as the model of Guo [23] (under tension and compression) and diverse surface interaction with coefficient of friction equal to 0.1 . The simulation was interrupted when the numerical model achieved $179.94 \mathrm{kN}$.m, close to the value achieved during the experimental test (163 kN.m). Due to its strong non-linear behavior, ABNT NBR 8800:2008 [8] and the Eurocode 3:2005 [30] recommend the rotational stiffness to be calculated at $2 / 3$ of maximum bending moment. Hence, taking the experimental model as reference, the values of the main parameters obtained from the curves Moment vs Rotation of experimental and numerical models are shown in Table 5.

Since a representative numerical model was defined, it was also possible to analyze the reinforcement strain besides the maximum values of bending moment and rotational stiffness. In the real scale test, the axial strain of negative rebars in the slab was measured and recorded using strain gages, so that the experimental strain could be compared to the numerical strain. When comparing it, it

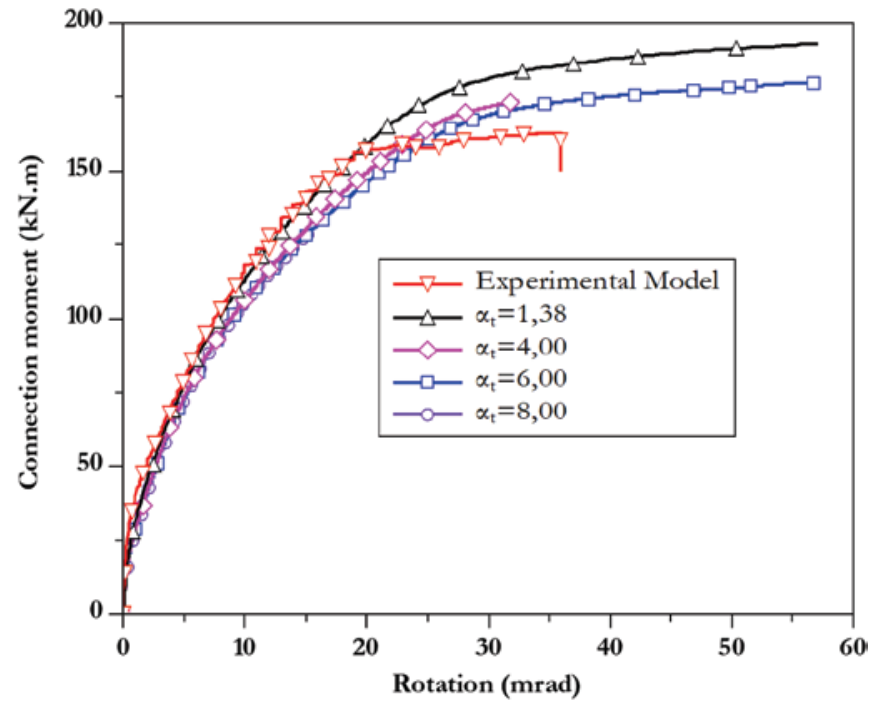

Figure 15

Influence of $\alpha_{\dagger}$ parameter 
Table 5

Values of bending moment, rotation and stiffness of experimental and numerical models

\begin{tabular}{cccccccc}
\hline Model & $\begin{array}{c}\text { Ultimate } \\
\text { moment } \\
(\mathrm{kN} . \mathrm{m})\end{array}$ & $\begin{array}{c}\mathbf{2 / 3} \text { Ultimate } \\
\text { moment } \\
(\mathrm{kN} . \mathrm{m})\end{array}$ & $\begin{array}{c}\Delta \\
(\%)\end{array}$ & $\begin{array}{c}\text { Rotation } \\
\left(\mathrm{m}_{\text {rad }}\right)\end{array}$ & $\begin{array}{c}\Delta \\
(\%)\end{array}$ & $\begin{array}{c}\text { Stiffness } \\
\left(\mathrm{kN} . \mathrm{m} / \mathrm{m}_{\text {rad }}\right)\end{array}$ & $\begin{array}{c}\Delta \\
(\%)\end{array}$ \\
\hline Experimental & 163.00 & 108.67 & +9.4 & 8.90 & +31.5 & 12.21 & -32.3 \\
Numerical & 179.94 & 119.96 & 12.99 & & 9.23 & -23 \\
\hline
\end{tabular}

is possible to notice that the interruption of the simulation occurred for a load level where the reinforcing steel was already showing considerable plastic strains, characterizing adequately the failure mode observed in the experimental model, namely the yielding of negative reinforcement (Figure 16). There is a good agreement between strains observed in the numerical and experimental models considering the analyzed items.

In addition to the strains, it is possible to check the stress distribution in the numerical model and when analyzing the main stresses corresponding to the last load increment, it can be observed that the ultimate reinforcement stress reaches $593 \mathrm{MPa}$ in many of the reinforcement elements (Figure 17). This stress value is identical to the experimental value corresponding to the reinforcement yielding strength. It can also be noticed that the higher stresses occur in the longitudinal rebars closer to the column face and that the stress level reduces as the distance from the symmetrical axis increases. The overview of stresses in the concrete slab (Figure 18) allows the clear identification of both the tension (upper side of slab) and the compression (lower side of slab) regions. In the portion under tension, the maximum stresses were around $1.834 \mathrm{MPa}$ when the simulation was interrupted, indicating that the stresses concrete were near its tensile ultimate stress (Table 1).

Therefore, considering the reinforcement and slab stresses overview (Figures 17 and 18), it is possible to note that the numerical modelling interruption occurred due to the high level of strain and stresses in many rebars, corresponding to the yielding of rebars,

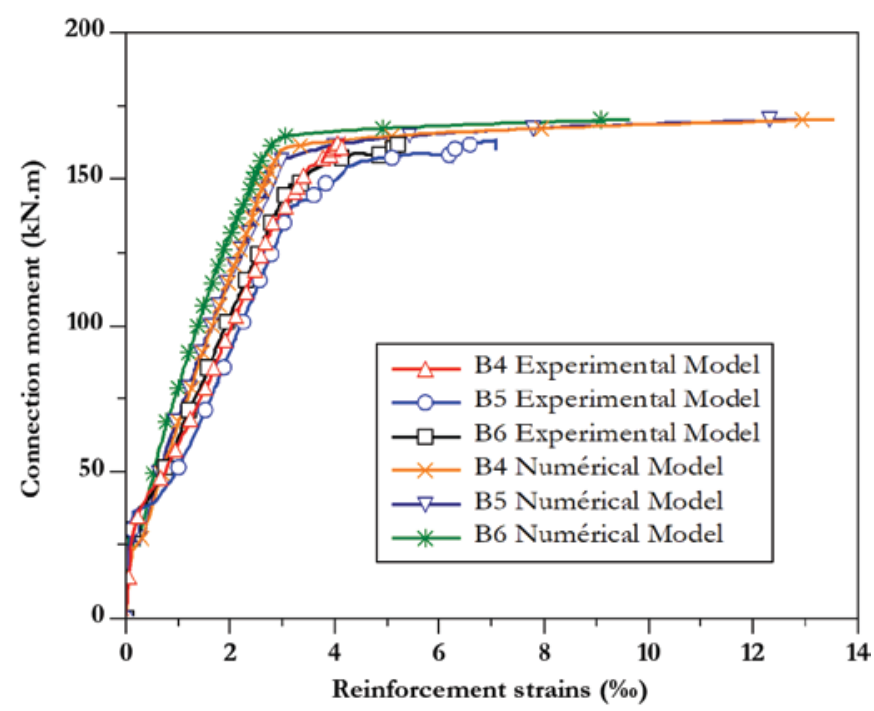

Figure 16

Moment vs. Reinforcing bars strains behavior that is the same failure mode observed in the experimental test [10]. The overview of stresses in the concrete and reinforcement validate the good representation of numerical results when compared to the experimental ones. Whereas, the stress levels measured in the steel beam profile (Figure 19a) and in the steel plate (Figure 19b) are much smaller than the steel yield strength (Table 1 ), indicating that these components were not very demanded. This was also observed in the test [10].

Due to good agreement in global and local levels (Figures 15 and 16) and failure mode good representation, the numerical model developed in this research was validated for representing the experimental behavior [10]. In conclusion, the validated numerical model is characterized by steel elements represented using perfectly elastoplastic behavior and strength values according to Table 1, constitutive model of Guo [23] for the concrete and parameters of plasticity according to Table 3 , contact interactions according item 3.3 and steel-concrete friction coefficient of 0.1 . The constraint of reinforcement and concrete slab and the materials behavior were represented using embedded region command.

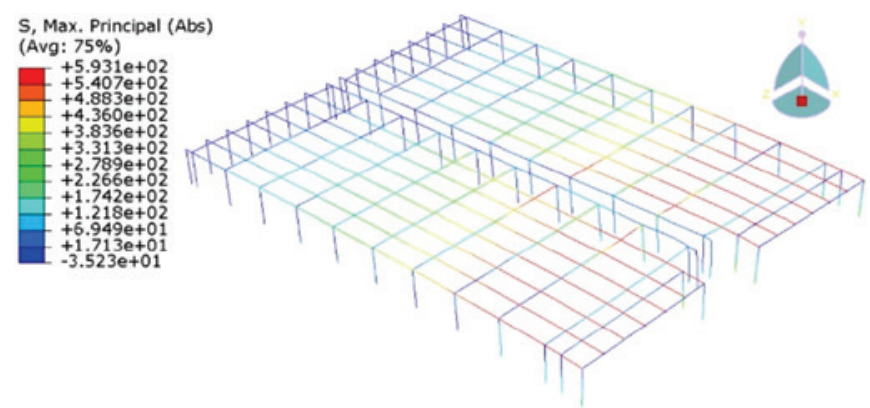

Figure 17

Overview of principal stresses in the reinforcing bars

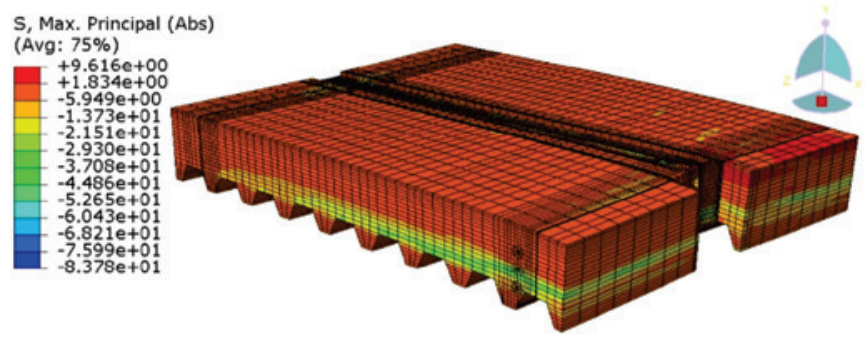

Figure 18

Overview of principal stresses on the concrete slab for the last load increment 


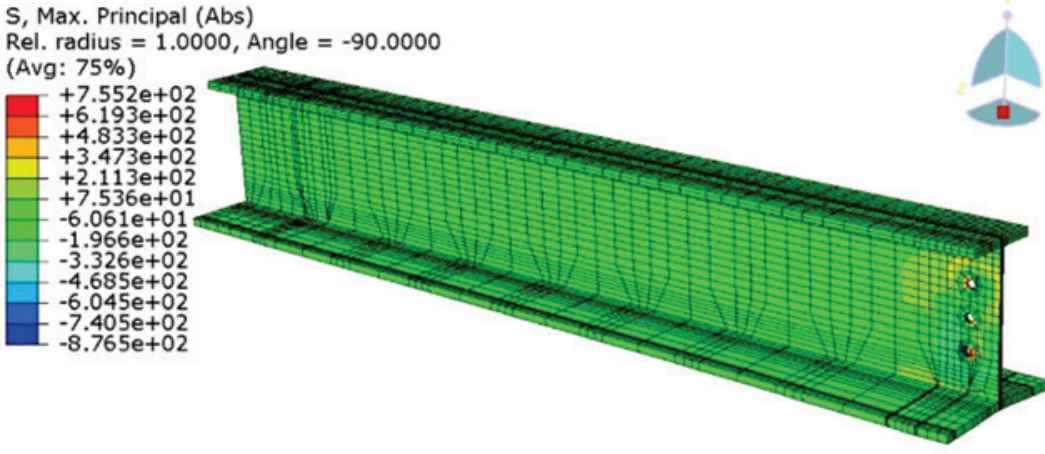

a

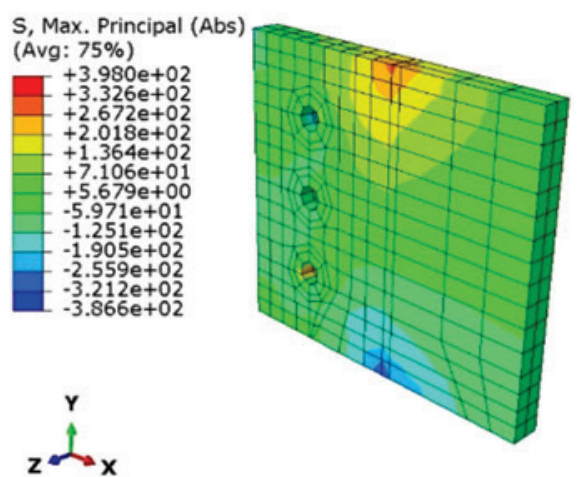

b

\section{Figure 19}

Final overview of the principal stresses in the beam and steel plate

\section{Conclusions}

Studies about composite slim floor systems are usually addresses in the behavior of the partially encased composite beams. Additionally, most of the researches until now are limited to beam-to-column composite connections with steel columns and conventional composite beams. Researches on the structural behavior of composite connection between concrete filled steel tube columns and composite beams are very rare and, more rarely, studies about composite connections with composite columns and slim floor beams.

The main aim of the present study was the development of a numerical modelling to represents the Moment vs. Rotation behavior of the beam-to-column composite connection with concrete filled steel tube column and slim floor composite beams. This is a complicate numerical model due to the number of components, several steel-concrete interactions and the non-linearity behavior of the materials. The numerical modelling results shown the perfect bond was not a good approach to represents the connection behavior and it was necessary to introduce several contact interaction. The influence of the concrete model was very significant and the first results showed that the headed studs have to be represented to improve the numerical response. The contact interactions were included in the numerical model and the numerical response has a good agreement with the experimental results however, there were some problems of convergence. These convergence problems were solved changing some parameters of the concrete damage plasticity and the results showed the insignificant influence of the eccentricity and dilatation angle for both convergence and connection behavior. On the other hand, the convergence was improved for high values of viscosity; however, the stiffness of the numerical model was higher than the experimental value. Finally, the convergence problem was solved when it was adopted the elasticperfectly plastic model for all steel components. The steel-concrete composite behavior was better represented by Embedded Region. Therefore, a numerical model was validate against experimental results and this numerical approach can be used to represents the beam-to-column behavior with square concrete filled steel tube column and slim composite floor beams. This approach also can be used in future parametric analyses considering several materials strengths, reinforcement ratios and geometries of components.

\section{Acknowledgements}

The authors are grateful to Fapesp - Fundação de Amparo à Pesquisa do Estado de São Paulo - for the financial support given to the realization of the experimental test (Fapesp process no. 2002/14209-4).

\section{References}

[1] BERNUZZI, C.; GADOTTI, F.; ZANDONINI, R. Semicontinuity in slim floor steel-concrete composite systems. In: Proceedings of the $1^{\text {st }}$ European Conference on Steel Structures. 1995, Athens, p. 287-294.

[2] MA, Z.; MAKELAINEN, P. Behaviour of composite slim floor structures in fire. Journal of Structural Engineering, v. 126 , n. 7, 2000; p. 830-837.

[3] LAWSON, R. M.; MULLETT, D. L.; RACKHAM, J. W. Design of Asymmetric "Slimflor" Beams using Deep Composite Decking. The Steel Construction Institute, Publication 175, 1997.

[4] RAMOS, A. L. Análise numérica de pisos mistos aço-concreto de pequena altura, São Carlos, 2012, Dissertação (Mestrado) - Escola de Engenharia de São Carlos, Universidade de São Paulo, $138 \mathrm{p}$.

[5] DE NARDIN, S.; EL DEBS, A. L. H. C. Study of partially encased composite beams with innovative position of stud bolts. Journal of Constructional Steel Research, v. 65, n. 2, 2009; p. 342-350.

[6] WANG, Y.; LU, Y.; SHI, Y.; ZHANG, R. Loading capacity of composite slim frame beams. Journal of Constructional Steel Research, v. 65, n. 3, 2009; p. 650-661.

[7] PUHALI, R.; SMOTLAK, I.; ZANDONINI ,R. Semi-rigid composite action: experimental analysis and suitable model. Journal of Constructional Steel Research, v. 15, 1990; p. 121-151. 
ASSOCIAÇÃO BRASILEIRA DE NORMAS TÉCNICAS. NBR 8800:2008. Projeto de estruturas de aço e de estruturas mistas de aço e concreto de edifícios. Rio de Janeiro, 2008.

[9] MALASKA, M. Behaviour of a semi-continuous beam-column connection for composite slim floors, Helsinki, 2000, Thesis (Doctorate) - Helsinki University of Technology, $102 \mathrm{p}$.

[10] DE NARDIN, S.; EL DEBS, A. L. H. C. Composite connections in slim-floor system: An experimental study. Journal of Constructional Steel Research, v. 68, n. 1, 2012; p. 78-88.

[11] ABAQUS. Software Documentation. Version 6.17 by SIMULIA.

[12] FU, F.; LAM, D.; YE, J. Parametric study of semi-rigid composite connection with 3-D finite element approach. Engineering Structures, v. 29, 2007; p. 888-898.

[13] GIL, B.; GONI, R.; BAYO, E. Experimental and numerical validation of a new design for three-dimensional semi-rigid composite joints. Engineering Structures, v. 48, 2013; p. 55-69.

[14] ROCHA, F. M. Pilares de aço e mistos de aço e concreto inseridos em paredes em situação de incêndio, São Carlos, 2016, Tese (Doutorado) - Escola de Engenharia de São Carlos, Universidade de São Paulo, 262 p.

[15] AMADIO, C.; BEDON, C.; FASAN, M. Numerical assessment of slab-interaction effects on the behaviour of steelconcrete composite joints. Journal of Constructional Steel Research, v. 139, 2017; p. 397-410.

[16] SHERBOURNE, A.N.; BAHAARI, M.R. 3D simulation of bolted connections to unstiffened columns - I. T-stub connections. Journal of Constructional Steel Research, v. 40, 1996; p. 169-187.

[17] MAGGI, Y. I. Análise do comportamento estrutural de ligações parafusadas viga-pilar com chapa de topo estendida, Sõ carlos, 2004, Tese (Doutorado) - Escola de Engenharia de São Carlos, Universidade de São Paulo, 269 p.

[18] COMITÉ EUROPÉEN DE NORMALISATION. Eurocode 3: Design of steel structures - Part 1-4: General rules Supplementary rules for stainless steels - EN 1993-1-4, Brussels, 2006.

[19] JANKOWIAK, T.; LODYGOWSKI, T. Identification of parameters of concrete damage plasticity constitutive model. Foundations of Civil and Enviromental Engineering, v. 06, 2005; p. 53-69.

[20] KIRCHHOF, L. D. Uma contribuição ao estudo de vigas mistas aço-concreto simplesmente apoiadas em temperatura ambiente e em situação de incêndio, São Carlos, 2004, Dissertação (Mestrado) - Escola de Engenharia de São Carlos, Universidade de São Paulo, 143 p.

[21] SILVA, H. P. Simulação Numérica do Comportamento de Conectores de Cisalhamento Tipo Crestbond, Vicoça, 2013, Dissertação (Mestrado) - Universidade Federal de Viçosa, $109 \mathrm{p}$.

[22] CARREIRA, D.J.; CHU, K. H. Stress-strain relationship for reinforced concrete in tension. ACl Journal, v. 83, 1986; p. 21-28.
[23] GUO, Z. Principles of reinforced concrete, Oxford: Elsevier, 1ed, 2013, 590p.

[24] COMITÉ EUROPÉEN DE NORMALISATION. Eurocode 2: Design of concrete structures - Part 1-1: General rules and rules for buildings - EN 1992-1-1, Brussels, 2004.

[25] CARREIRA, D.J.; CHU, K. H. Stress-strain relationship for plain concrete in compression. ACl Journal, v. 82, 1985; p. 797-804.

[26] ATAEI, A.; BRADFORD, M. A.; VALIPOUR, H. R. Moment-rotation model for blind-bolted flush end-plate connections in composite frame structures. Journal Structural Engineering, v.141, 2015; p. 401-421.

[27] KOCHEM, R. F. F. Modelagem numérica de piso misto de aço e concreto de pequena altura: ênfase à ligação vigapilar, São Carlos, 2018, Dissertação (Mestrado) - Universidade Federal de São Carlos, 106 p.

[28] GIL, B.; BAYO, E. An alternative design for internal and external semi-rigid composite joints. Part II: Finite elemento modelling and analytical study. Engineering Structures, v. 30, 2008; p. 232-246.

[29] McCORMICK, J.; NAGAE, T.; IKENAGA, M.; ZHANG, P.; KATSUO, M.; NAKASHIMA, M. Investigation of the sliding behavior between steel and mortar for seismic applications in structures. Earthquake Engineering and Structural Dynamics, v. 38, 2009; p. 1401-1419.

[30] COMITÉ EUROPÉEN DE NORMALISATION. Eurocode 3: Design of structures - Part 1-8: Design of joints - EN 1993-1-8, Brussels, 2005. 